\title{
Hubungan pengetahuan dengan motivasi mencegah komplikasi pada penderita diabetes melitus
}

\author{
Andoko ${ }^{1}$, Dimas Ning Pangesti ${ }^{2}$, Nurhayati ${ }^{1 *}$ \\ 1Program Studi IImu Keperawatan Universitas Malahayati. *Email: nurahmantahir785@gmail.com \\ ${ }^{2}$ Akademi Keperawatan Baitul Hikmah Bandar Lampung.
}

\section{Abstract \\ Knowledge and motivation in management of diabetes mellitus complicating}

Background: The increasing of diabetes mellitus prevalence and complication occurrence. The number of diabetes mellitus in 2018, there were 654 patients. A pre-survey in January 2019 on 15 respondents, 50.7\% patients had a poor knowledge and $54.9 \%$ had a poor motivation to prevent complication of diabetes mellitus. Purpose: To know the correlation between knowledge and motivation in management of diabetes mellitus complicating

Method: A quantitative with cross sectional method. The population was all outpatient at Internal Polyclinic of Bhayangkara Polda Lampung Hospital and the samples were 48 patients. The instruments were questionnaires. The data analsysi by chi square.

Results: Shows that 30 respondents $(62.5 \%)$ had good a knowledge. The other 27 respondents $(56.3 \%)$ had high motivation in management of diabetes mellitus complicating. There was correlation between knowledge and motivation in management of diabetes mellitus complicating ( $p$ value 0.029, OR 4.7 ).

Conclusion: There was correlation between knowledge and motivation in management of diabetes mellitus complicating. The health practitioners should intensify the health promotion to patient by displaying posters and distributing leaflet for hospital visitors to improve their knowledge.

\section{Keywords: Knowledge; Motivation; Management; Diabetes mellitus; Complicating}

Pendahuluan: Adanya peningkatan prevalensi penderita DM, serta meningkatnya angka kejadian komplikasi penderita DM di RS Bhayangkara Polda Lampung tahun 2018 berjumlah 654 penderita. Dari presurvei bulan januari 2019 didapat 15 responden, tingkat pengetahuan kurang sekitar $(50,7 \%)$ dan yang mempunyai motivasi rendah $(54,9 \%)$.

Tujuan: Untuk mengetahui hubungan antara pengetahuan dan motivasi penderita diabetes melitus.

Metode: Penelitian kuantitatif, dan menggunakan cross sectional study, populasipasien yang menderita diabetes melitus di Poliklinik Penyakit Dalam RS Bhayangkara Polda Lampung. Sampelnya sebanyak 48 orang, instrumen menggunakan kuesioner dan analisa data menggunakan uji chi square.

Hasil: Tingkat pengetahuan baik 30 responden (62.5\%), motivasi tinggi 27 responden (56.3\%).Ada hubungan antara pengetahuan dengan motivasi penderita DM dalam mencegah komplikasi ( $p$ value 0,029 . OR 4,7).

Simpulan: Ada hubungan antara pengetahuan dengan motivasi penderita DM dalam mencegah komplikasi.

Saran kepada RS Bhayangkara meningkatkan kegiatan promosi kesehatan tentang pola hidup yang baik bagi klien DM, dengan memasang poster dan membagian leaflet.

\section{Kata kunci: Pengetahuan; Motivasi; Komplikasi; Diabetes melitus}

\section{PENDAHULUAN}

Diabetes Melitus merupakan penyakit endokrin yang paling sering.Frekuensi sebenarnya sulit diperoleh karena perbedaan standar diagnosis tetapi mungkin antara 1 dan 2 persen jika hiperglikemia puasa merupakan kriteria diagnosis. Penyakit ini ditandai oleh kelainan metabolik dan komplikasi panjang yang melibatkan mata,ginjal, saraf, dan pembuluh darah (Harrison, Wilson, \& Kasper, 2015)

Menurut World Health Organization (WHO) 2016.Diabetes Melitus tipe II merupakan salah satu penyakit degenartif.Diabetes melitus merupakan salah satu dari empat prioritas penyakit tidak menular.Diabetes melitus merupakan penyebab utama untuk kebutaan, serangan jantung, stroke, 
Hubungan pengetahuan dengan motivasi mencegah komplikasi pada penderita diabetes melitus

gagal ginjal, dan amputasi kaki. Hal tersebut dikarenakan penyakit ini memiliki berbagai macam faktor risiko mulai dari gaya hidup, perilaku merokok serta pola makan individu yang kurang baik .Kejadian Diabetes Melitus tipe II terus mengalami peningkatan.Sejak tahun 1980 hingga 2014. Peningkatan prevalensi Diabetes Melitus yang sebagian besar merupakan tipe II sebanyak $3,8 \%$ (Kementerian Kesehatan Republik Indonesia, 2018; World Health Organization, 2016).

Berdasarkan data dari Diabets Atlas Edisi ke-8 dikumpulkan mulai Januari 2015 hingga Desember 2016. IDF memprediksi kejadian Diabetes Melitus akan meningkat drastis pada tahun 2045 terdapat pada regionSouth-EastAsia dan Africa dengan masing-masing prevalensi meningkat dari 2017 hingga 2045 sebanyak $84 \%$ dan $156 \%$. Sedangkan IDF memprediksi jumlah penderita diabetes pada tahun 2045 akan sampai pada angka 629 juta penderita Diabetes Melitus. Di dunia Indonesia menempati urutan ke-6 terbesar, dengan jumlah 10,3 juta. Dan diabetes melitus penyebab 6\% total kematian pada masayarakat Indonesia semua umur (Kementerian Kesehatan Republik Indonesia, 2018; Ogurtsova, 2017)

Di Lampung sendiri berdasarkan data dari Dinas Kesehatan provinsi Lampung (2016) didapatkan data pola penyakit penderita puskesmas dan rumah sakit dari berbagai tingkatan umur, jumlah kasus DM menempati urutan kedua setelah penyakit neoplasma ganas, dan penyebab kematian pasien dirawat di Rumah Sakit Provinsi Lampung. Diabetes melitus dan merupakan urutan ke 8 dari 10 penyakit terbesar yang ada di Provinsi Lampung.

Usaha untuk menjaga agar kadar gula tetap dapat mendekati normal bisa tergantung dari motivasi serta pengetahuan penderita mengenai penyakitnya. Pengetahuan yang rendah menyebabkan pasien kurang termotivasi untuk datang kepelayanan kesehatan karena tidak merasa ada keluhan atau sakit (Pollard, Cordona \& Baker, 2002; Ariani, 2011). Pengetahuan yang rendah dapat mempengaruhi persepsi pasien tentang penyakit diabetes melitus melitus (Sousa \& Zauseniewski, 2005; Azis \& Aminah, 2018). Menurut teori prilaku selain dari pengetahuan motivasi juga erat kaitannya dengan prilaku seseorang, karena dengan adanya pengetahuan maka akan muncul motivasi dalam diri seseorang untuk berprilaku (Notoadmojo, 2012; Mulya, \&
Betty, 2016; Kahan, Gielen, Fagan, \& Green, 2014).

Sebagaimana Persatuan Endrokrinologi Indonesia (2011), menyatakan terdapat empat pilar penatalaksanaan DM, antara lain edukasi, terapi gizi medis, latiham jasmani, dan intervensi farmakologis. Penatalaksanaan DM dimulai dengan edukasi untuk mengubah gaya hidup dan prilaku pasien. Berdasarkan laporan dari Rekam medik RS. Bhayangkara Polda Lampung (2018), terdapat jumlah pasien yang menderita Diabetes Meltus mengalami peningkatan setiap tahunnya, sekitar $\pm 10 \%$ dalam setiap tahun, dan jumlah pasien diabetes melitus pada tahun 2018 berjumlah 654 penderita. Sementara menurut keterangan dari perawat yang bertugas di Poliklinik Penyakit Dalam RS. Bhayangkara Polda Lampung, mengemukan bahwa pengetahuan penderita mengenai penyakit serta cara pencegahan komplikasi yang mungkin timbul juga dirasakan masih sangat kurang. Hal ini dapat dilihat dari adanya pasien yang tidak rutin memeriksakan gula darahnya setiap bulannya, dan masih kurangnya pasien melakukan pantangan makanan atau mengatur diet makanannya, sehingga gula darahnya tinggi setiap kali kontrol ke rumah sakit. Dari presurvei yang dilakukan 1 minggu pada bulan januari 2019 didapat 15 responden, dan didapatkan bahwa pasien dengan tingkat pengetahuan kurang sekitar $(50,7 \%)$ dan yang mempunyai motivasi rendah $(54,9 \%)$.

Berdasarkan masalah diatas, maka peneliti tertarik untuk melakukan penelitian tentang "Hubungan Pengetahuan Dengan Motivasi Mencegah Komplikasi Pada Pasien Diabetes melitus Melitus Di Poli Penyakit Dalam Rumah Sakit Bhayangkara Polda Lampung Tahun 2019".

\section{METODE PENELITIAN}

Penelitian kuantitatif dengan metode deskripsi korelasi dengan rancangan cross sectional. Populasinya pasien yang menderita diabetes melitus yang berobat jalan di Poliklinik Penyakit Dalam RS Bhayangkara Polda Lampung. Dengan total Sampling didapatkan 48 responden. Pengumpulan data untuk meneliti motivasi mencegah komplikasi menggunakan kuesioner terdiri dari 20 pertanyaan dengan skor teringgi $\geq$ 60 (12 pertanyaan nilai betul) dengan kriteria motivasi tinggi dan pertanyaan dengan skor terendah < 60 dengan kriteria motivasi rendah. Instrumen telah di lakukan uji validitas dan

Andoko', Dimas Ning Pangesti ${ }^{2}$, Nurhayati*

'Program Studi 1lmu Keperawatan Universitas Malahayati. *Email: nurahmantahir785@gmail.com

${ }^{2}$ Akademi Keperawatan Baitul Hikmah Bandar Lampung. 
Hubungan pengetahuan dengan motivasi mencegah komplikasi pada penderita diabetes melitus

reabilitas dengan nilai hasil a 0,63 yang lebih besar dari r table (Sujana, 2012).

Pengukuran pengetahuan mengunakan kuesioner pengetahuan sebanyak 20 pertanyanan. Dengan skor terendah 0 dan tertinggi 20, adapun kriteria baik dengan nilai $\geq 60$ (12 pertanyaan nilai betul) dan sebaliknya pengetahuan di katakan buruk apabila nilai < 60 (Piolasari, 2012). Analisis ini menggunakan uji chi square. Penelitian ini sudah melalui proses layak yang dikeluarkan oleh Komisi etik penelitian kesehatan Universitas Malahayati Bandar Lampung dengan No. 480/EC/KEP-UNMAL///2019.

\section{HASIL}

Tabel 1. Karakteristik Responden ( $\mathrm{N}=48$ )

\begin{tabular}{|c|c|c|}
\hline Karakteristik & Frekuensi (f) & Persentase (\%) \\
\hline \multicolumn{3}{|l|}{ Jenis Kelamin: } \\
\hline Laki-laki & 20 & 41.7 \\
\hline Perempuan & 28 & 58.3 \\
\hline Umur: & & 41.7 \\
\hline$<50$ Tahun & 20 & 58.3 \\
\hline$\geq 50$ Tahun & 28 & \\
\hline \multicolumn{3}{|l|}{ Pendidikan: } \\
\hline Tidak Sekolah & 1 & 2.1 \\
\hline Tamat SD & 7 & 14.6 \\
\hline Tamat SMP & 9 & 18.8 \\
\hline Tamat SMA & 21 & 43.8 \\
\hline Tamat & 10 & 20.8 \\
\hline \multicolumn{3}{|l|}{ Akademi/Perguruan } \\
\hline \multicolumn{3}{|l|}{ Tinggi } \\
\hline \multicolumn{3}{|l|}{ Pekerjaan: } \\
\hline PNS & 4 & 8.3 \\
\hline Ibu Rumah Tangga & 12 & 25.0 \\
\hline Polri & 13 & 27.1 \\
\hline Wiraswasta & 7 & 14.6 \\
\hline Lain-lain & 12 & 25.0 \\
\hline \multicolumn{3}{|l|}{ Pengetahuan: } \\
\hline Baik & 30 & 62.5 \\
\hline Buruk & 18 & 37.5 \\
\hline \multicolumn{3}{|l|}{ Motivasi: } \\
\hline Tinggi & 27 & 56.2 \\
\hline Rendah & 21 & 43.8 \\
\hline
\end{tabular}

Berdasarkan Tabel 1. diketahui bahwa sebagian besar responden adalah perempuan yaitu sebanyak 28 responden $(58.3 \%)$, berusia $\geq 50$ Tahun yaitu sebanyak 28 responden $(58,3 \%)$, merupakan tamatanSekolah Menengah Atas yaitu sebanyak 21 responden (43,8\%), merupakan anggota Polri yaitu sebanyak 13 responden (27.1\%).dan di ketahui juga bahwa sebagian besar responden menyatakan dengan tingkat pengetahuan baik yaitu sebanyak 30 responden (62.5\%), dengan hasil skor $>50 \%$. Motivasi tinggi dalam mencegah komplikasi penyakit DM yaitu sebanyak 27 responden (56.2\%), dengan hasil skor $\geq$ mean/49.7.

Andoko', Dimas Ning Pangesti ${ }^{2}$, Nurhayati*

'Program Studi llmu Keperawatan Universitas Malahayati. *Email: nurahmantahir785@gmail.com

${ }^{2}$ Akademi Keperawatan Baitul Hikmah Bandar Lampung. 
Hubungan pengetahuan dengan motivasi mencegah komplikasi pada penderita diabetes melitus

Tabel 2. Hubungan Antara Pengetahuan Dengan Motivasi

\begin{tabular}{|c|c|c|c|c|c|c|c|}
\hline \multirow{3}{*}{ Pengetahuan } & \multicolumn{4}{|c|}{ Motivasi } & \multirow{3}{*}{$\begin{array}{c}\text { Total } \\
\mathrm{N}\end{array}$} & \multirow{3}{*}{$p$-value } & \multirow{3}{*}{$\begin{array}{c}\text { OR } \\
\text { (Cl 95\%) }\end{array}$} \\
\hline & \multicolumn{2}{|c|}{ Tinggi } & \multicolumn{2}{|c|}{ Rendah } & & & \\
\hline & $n$ & $\%$ & $\mathrm{n}$ & $\%$ & & & \\
\hline Baik & 21 & 43.7 & 9 & 21.8 & 30 & 0,029 & $4,7(1,3-16,4)$ \\
\hline Buruk & 6 & 12.6 & 12 & 22.0 & 18 & & \\
\hline Total & 27 & 56.3 & 21 & 43.8 & 48 & & \\
\hline
\end{tabular}

Hasil penelitian didapatkan bahwa dari 30 responden dengan pengetahuan baik, sebanyak $21(43.75 \%)$ orang (memiliki motivasi tinggi dalam mencegah komplikasi dan 9 responden $(18.75 \%)$ memiliki motivasi rendah dalam mencegah komplikasi. Sedangkan dari 18 responden dengan pengetahuan tidak baik, sebanyak 6 orang $(12,55$ $\%)$ memiliki motivasi tinggi dalam mencegah komplikasi dan 12 responden (25.5\%) memiliki motivasi rendah dalam mencegah komplikasi. Hasil uji chi square didapatkan nilai $p$ value 0,029 , artinya lebih kecil dibandingkan dengan nilai alpha $(0,029<0,05)$. Dengan demikian dapat disimpulkan secara statistik dengan derajat kepercayaan $95 \%$, diyakini terdapat hubungan antara pengetahuan dengan motivasi penderita DM dalam mencegah komplikasi di Poliklinik RS.Bhayangkara Polda Lampung Tahun 2019. Sedangkan hasil uji OR diperoleh nilai 4,7 (Cl 96\% 1,3-16,3), artinya pengetahuan baik menyebabkan responden 4,7 kali lebih besar untuk memiliki motivasi tinggi dalam mencegah komplikasi dibandingkan dengan yang memiliki pengetahuan tidak baik.

\section{PEMBAHASAN}

\section{Pengetahuan}

Hasil penelitian menunjukkan bahwa sebagian besar responden menyatakan dengan tingkat pengetahuan baik yaitu sebanyak 30 responden $(62.5 \%)$, dengan hasil skor $>50 \%$. Pengetahuan penderita tentang DM merupakan sarana yang dapat membantu penderita menjalankan penanganan DM selama hidupnya sehingga semakin baik penderita mengerti tentang penyakitnya semakin mengerti bagaimana harus berperilaku dalam penanganan penyakitnya (Purnamasari,Waspadji, Adam, Rudijanto, \& Tahapary, 2014).Pengetahuan pasien tentang penyakit DM dianggap penting, karena selain untuk memahami penyakit tersebut tetapi pasien dapat menentukan langka-langka yang perlu diambil dalam rangka beratnya komplikasi penyakit. Hal ini sejalan dengan penelitian sebelunya didapatkan sebanyak 71 orang $(68,8 \%)$ berpengetahuan baik dan 26 orang $(26,0 \%)$ berpengetahuan kurang (Tombokan, 2015).

Dalam penelitian ini distribusi umur responden menunjukkan sebagian besar responden berumur antara $>50$ tahun. Komposisi umur responden yang sebagian besar berusia 50 tahun ke bawah $(58,3 \%)$ memungkinkan responden masih memiliki kemampuan untuk menyerap informasi-informasi yang merupakan sumber dari pengetahuan tentang penyakit Diabetes Mellitus.

Distribusi karakteristik responden menurut jenis kelamin menunjukkan bahwa rata-rata adalah perempuan yaitu sebanyak 28 responden (58.3\%).Secara medis sebenarnya laki-laki memiliki resistensi yang lebih tinggi terhadap Diabetes Mellitus dibandingkan perempuan.Kejadian Diabetes Mellitus tipe 2 sangat dipengaruhi oleh resistensi insulin, sedangkan jenis kelamin mempengaruhi sensitivitas insulin dan otot rangka laki-laki lebih resisten dibandingkan perempuan (Kementerian Kesehatan Republik Indonesia, 2014). Dalam penelitian ini ternyata rata-rata responden adalah perempuan, kondisi ini disebabkan karena gaya hidup yang kurang baik, yaitu pola makan yang tidak teratur serta aktivitas yang tak menentu. $\mathrm{Hal}$ ini menunjukkan kelebihan mengkonsumsi lemak, maka lemak tersebut akan tersimpan di dalam ubuh dalam bentuk jaringan lemak yang dapat menimbulkan kenaikan berat badan (obesitas). Aktivitas fisik seperti pergerakan badan atau olahraga yang dilakukan secara teratur adalah usaha yang dapat dilakukan untuk menghindari kegemukan dan obesitas. Pada saat tubuh melakukan aktivitas atau gerakan maka sejumlah gula akan dibakar untuk dijadikan tenaga, sehingga jumlah gula dalam tubuh akan berkurang sehingga kebutuhan hormon insulin juga berkurang.

Distribusi responden menurut pendidikan menunjukkan rata-rata masih dalam kategori

Andoko', Dimas Ning Pangesti ${ }^{2}$, Nurhayati ${ }^{\text {* }}$

'Program Studi llmu Keperawatan Universitas Malahayati. *Email: nurahmantahir785@gmail.com

${ }^{2}$ Akademi Keperawatan Baitul Hikmah Bandar Lampung. 
Hubungan pengetahuan dengan motivasi mencegah komplikasi pada penderita diabetes melitus

pendidikan menengah dan atas yaitu tamat SMA sebanyak 21 responden (43.8\%). Pendidikan mempunyai peranan penting dalam pembentukan kecerdasan manusia maupun perubahan tingkah lakunya. Pendidikan mampu menumbuhkan kesadaran akan tanggung jawab untuk meningkatkan mutu dan taraf hidup, dan selanjutnya masyarakat berpendidikan akan lebih mampu dan sadar akan menjaga dan memelihara kesehatannya (Irawan, 2014).

Distribusi responden menurut pekerjaan meskipun proporsi terbanyak adalah Polri.Secara tidak langsung memang pekerjaan tidak dapat dikatakan berhubungan dengan pengetahuan seseorang, namun interaksi yang terjadi selama seseorang bekerja yang berhubungan terhadap pengetahuan. Interaksi yang dilakukan seseorang dengan orang lain selama melaksanakan pekerjaan, tidak hanya berkaitan dengan pekerjaan tersebut, mungkin saja berhubungan dengan tematema lain misalnya kehidupan rumah tangga dan masalah kesehatan. Ketika interaksi tersebut membahas tentang penyakit Diabetes Mellitus, maka secara tidak disadari pengetahuan seseorang tentang penyakit tersebut meningkat.

\section{Motivasi}

Hasil penelitian menunjukkan bahwa sebagian besar responden dengan motivasi tinggi dalam mencegah komplikasi penyakit DM yaitu sebanyak 27 responden (56.3\%), dengan haisl skor $\geq$ mean/49,7.Motivasi dapat memberikan pengaruh terhadap efikasi diri pasien DM tipe 2 dalam perawatan diri. Penelitian ini diperkuat dengan penelitian sebelumnya (Shigaki, Kruse, Mehr, Sheldon, Ge, Moore, \& Lemaster, 2010; Kusuma, \& Hidayati, 2013). Motivasi yang tinggi akan memiliki frekuensi perawatan diri yang baik terutama untuk diet dan pemeriksaan kadar gula darah. Penelitian ini sejalan dengan penelitian yang dilakukan oleh peneliti bahwa saat di wawancara responden mengatakan kurang termotivasi untuk melakukan perawatan mandiri kerena proses yang lama dan biaya yang mahal.

Penyakit Diabetes Mellitus merupakan penyakit yang akan diderita seumur hidup, hal tersebut karena diabetes tidak dapat disembuhkan sepenuhnya. Seseorang yang didiagnosis menderita Diabetes Mellitus harus merubah seluruh gaya hidupnya guna menghindari terjadinya komplikasi atau penyakit yang lebih parah (Latifah, 2017). Perubahan yang terjadi pada gaya hidupnya, terutama soal makanan, pola istirahat, dan sebagainya seringkali membuat klien tidak sabar dan cenderung mengabaikannya. Penanganan Diabetes Mellitus sangat memerlukan motivasi dan ketekunan yang intens dari kliennya. Apabila klien sedikit saja lalai dalam mengontrol kadar gulanya, enggan berolah raga secara teratur, dan menjalani pola makan yang tidak sesuai, maka akan menyebabkan munculnya komplikasi yang tidak diinginkan (Piolasari, 2012). Motivasi pada klien Diabetes Mellitus adalah dorongan klien untuk mengatur pola hidupnya guna menghindari terjadinya komplikasi atau keparahan Diabetes Mellitus.Tinggi rendahnya motivasi klien diabetes dipengaruhi oleh berbagai faktor yaitu pengetahuan, sikap, jarak, kondisi sosial ekonomi, sumber informasi, sosial budaya, mutu pelayanan.

\section{Hubungan antara pengetahuan dengan motivasi penderita DM dalam mencegah komplikasi}

Hasil penelitian menunjukkan nilai $p$ value 0,029 , artinya lebih kecil dibandingkan dengan nilai alpha $(0,029<0,05)$. Dengan demikian dapat disimpulkan secara statistik dengan derajat kepercayaan $95 \%$, diyakini terdapat hubungan antara pengetahuan dengan motivasi penderita DM dalam mencegah komplikasi di Poliklinik RS.Bhayangkara Polda Lampung Tahun 2018 (OR $4,7)$.

Dan penelitian ini berhasil membuktikan adanya hubungan tingkat pengetahuan dengan motivasi mencegah komplikasi pada klien Diabetes Mellitus sesuai dengan teori (Kumar, Cotran, \& Robbins, 2007; Ramadhan, \& Marissa, 2015). yang menjelaskan bahwa diduga pengetahuan merupakan variabel yang mempengaruhi minat dan daya dorong yang dimiliki sekelompok kebutuhan pada individu tertentu dan dalam hal ini klien Diabetes Mellitus dalam mencegah komplikasi.

Berdasarkan hasil penelitian maka semakin baik pengetahuan klien Diabetes Mellitus maka semakin tinggi motivasi untuk mencegah komplikasi Hasil penelitian ini ternyata sesuai dengan hasil penelitian-penelitian sebelumnya. Penelitian (Mulya, \& Betty, 2016). Yang menyimpulkanada hubungan antara pengetahuan dengan mencegah ulkus diabetikum di RS Achmad Mochtar Bukittinggi.tahun 2014 ( $p=0,000$, $\mathrm{OR}=23,111$ ) dan terdapat hubungan antara

Andoko', Dimas Ning Pangesti ${ }^{2}$, Nurhayati*

'Program Studi llmu Keperawatan Universitas Malahayati. *Email: nurahmantahir785@gmail.com

${ }^{2}$ Akademi Keperawatan Baitul Hikmah Bandar Lampung. 
Hubungan pengetahuan dengan motivasi mencegah komplikasi pada penderita diabetes melitus

motivasi dengan mencegah ulkus diabetikum di RS Achmad Mochtar Bukittinggi tahun 2014 $(p=0,000, O R=37,917)$.

Dalam penelitian ini didapatkan bahwa dari 30 responden dengan pengetahuan baik, sebanyak 9 responden $(30.0 \%)$ memiliki motivasi rendah dalam mencegah komplikasi. Hal ini dapat disebabkan oleh faktor umur yang sangat berpengaruh terhadap tingkah laku seseorang.Sehingga pasien yang telah berumur > 50 tahun mempunyai motivasi yang menurun dibandingkan dengan yang masih di bawah 50 tahun. Sedangkan dari 18 responden dengan pengetahuan tidak baik, sebanyak 6 orang $(33,3 \%)$ memiliki motivasi tinggi dalam mencegah komplikasi, hal ini dapat disebabkan karena faktor umur yang masih muda, sehingga keinginan untuk melakukan pencegahan terhadap komplikasi sangat tinggi, dengan menjaga pola makan yang baik, melakukan aktivitas fisik/olah raga serta melakukan pemeriksaan kesehatan.

\section{SIMPULAN}

Dari penelitian ini 30 responden dengan tingkat pengetahuan baik dan motivasi tinggi sebanyak 21 Orang (43.75\%) dan pengethuan baik yang memiliki motivasi rendah sebanya 9 orang $(18.75 \%)$ Ada hubungan antara pengetahuan dengan motivasi penderita DM dalam mencegah komplikasi di Poliklinik RS.Bhayangkara Polda Lampung Tahun 2018 ( $p$ value 0,029. OR 4,7).

\section{SARAN}

Klien dengan Diabetes Mellitus senantiasa meningkatkan pengetahuannya tentang perawatan penyakit. Dengan cara banyak membaca literatur, bertanya kepada petugas kesehatan, atau melaksanakan Small Group Discussion dengan sesame penderita guna serta selalu memupuk motivasi mereka untuk menjaga gaya hidup sehat mereka.

\section{DAFTAR PUSTAKA}

Ariani, Y. (2011). Hubungan antara motivasi dengan efikasi diri pasien DM tipe 2 dalam konteks asuhan keperawatan di RSUP. $\mathrm{H}$. Adam Malik Medan. Unpublished master's thesis) Universitas Indonesia, Depok, Indonesia.
Azis, A., \& Aminah, S. (2018). Pengetahuan, Motivasi dan Kepatuhan Diet Pasien DM Tipe II di Wilayah Kerja Puskesmas Kaliwungu Kendal. Jurnal Smart Keperawatan, 5(1), 7279.

Dinas Kesehatan Provinsi Lampung. (2016). Profil Provinsi Lampung Tahun 2015. Bandar Lampung: Dinas Kesehatan Pemerintah Povinsi Lampung.

Harrison, I., Wilson, B. W., \& Kasper, M. F. (2015). Prinsip-prinsip ilmu penyakit dalam, edisi 18. Jakarta: EGC.

Irawan, B. (2014). Hubungan Antara Tingkat Pengetahuan Tentang Komplikasi Hipertensi Dengan Perilaku Mengontrol Tekanan Darah Pada Penderita Hipertensi Di Desa Batuwarno Kecamatan Batuwarno Kabupaten Wonogiri (Doctoral dissertation, Universitas Muhammadiyah Surakarta).

Kahan, S., Gielen, A. C., Fagan, P. J., \& Green, L. W. (Eds.). (2014). Health behavior change in populations. JHU Press.

Kementerian Kesehatan Republik Indonesia. (2014). Situasi dan analisis diabetes. Jakarta, Pusat Data dan Informasi Kemenkes RI, 1-8.

Kementerian Kesehatan Republik Indonesia. (2018). Riskesdas: angka kejadian 10 penyakit di indonesia. French. Retrieved from http://www.who.int/about/licensing/\%5Cnhttp://a pps.who.int/iris/bitstream/10665/204871/1/9789 241565257_eng.pdf

Kumar, V., Cotran, R. S., \& Robbins, S. L. (2007). Buku ajar patologi. Edisi ke-7. Jakarta: EGC.

Kusuma, H., \& Hidayati, W. (2013). Hubungan antara motivasi dengan efikasi diri pada pasien diabetes mellitus tipe 2 di Persadia Salatiga. Jurnal Keperawatan Medikal Bedah, 1(2).

Lathifah, N. L. (2017). Hubungan durasi penyakit dan kadar gula darah dengan keluhan subyektif penderita diabetes melitus. Jurnal Berkala Epidemiologi, 5(2), 231-239.

Andoko', Dimas Ning Pangesti ${ }^{2}$, Nurhayati*

'Program Studi llmu Keperawatan Universitas Malahayati. *Email: nurahmantahir785@gmail.com

${ }^{2}$ Akademi Keperawatan Baitul Hikmah Bandar Lampung. 
Hubungan pengetahuan dengan motivasi mencegah komplikasi pada penderita diabetes melitus

Mulya, A. P., \& Betty, B. (2016). Hubungan Pengetahuan dan Motivasi Penderita Diabetesmellitus dengan Upaya Pencegahan Ulkus Diabetikum di Poli Penyakit dalam Rumah Sakit Achmad Mochtar Bukittinggi. Jurnal Kesehatan, 5(1).

Notoatmodjo, S. (2017). Promosi kesehatan dan ilmu perilaku. Jakarta: Rineka Cipta, 20.

Ogurtsova, K., (2017). IDF Diabetes Atlas: Global estimates for the prevalence of diabetes for 2015 and 2040. Diabetes research and clinical practice, $128,40-50$

Persatuan Endrokrinologi Indonesia . (2011). Konsensus Pengendalian dan Pencegahan Diabetes Melitus Tipe 2 di Indonesia.Diaksesdari: https//www.scribd.com/doc/...konsesus-DMPerkeni-2011

Piolasari,Y. (2012). Hubungan antara Pengetahuan dengan Pola Makan Pada Pasien Diabetes Melitus Tipe II di Rumah Sakit Bhayangkara Polda Lampung.(Skripsi Tidak dipublikasikan) PSIK Universitas Malahayati Bandar Lampung Tahun 2017

Pollard, G., Cardona, M., \& Sketcher-Baker, K. (2002). 2000 Chronic Diseases Surveys: Diabetes Prevalence and Management Report. Epidemiology Services Unit, Health Information Centre, Queensland Health.

Purnamasari, D., Waspadji, S., Adam, J. M., Rudijanto, A., \& Tahapary, D. (2014). Indonesian Clinical Practice Guidelines for Diabetes in Pregnancy. Journal of the ASEAN Federation of Endocrine Societies, 28(1), 9
Ramadhan, N., \& Marissa, N. (2015). Karakteristik Penderita Diabetes Mellitus Tipe 2 Berdasarkan Kadar Hba1c Di Puskesmas Jayabaru Kota Banda Aceh. Sel Jurnal Penelitian Kesehatan, 2(2), 49-56.

Shigaki, C., Kruse, R. L., Mehr, D., Sheldon, K. M., Ge, B., Moore, C., \& Lemaster, J. (2010). Motivation and diabetes selfmanagement. Chronic illness, 6(3), 202-214.

Sousa, V. D., \& Zauszniewski, J. A. (2005). Toward a Theory of Diabetes Self-Care Management. Journal of Theory Construction \& Testing, 9(2).

Sujana, S. (2012). Hubungan Motivasi Penderita Diabetes Melitus dengan Prilaku Mengontrol Gula Darah di Puskesmas Panongan Kab. Majalengka. (Skripsi PSIK Cirebon). Diakses dari: https://fdokumen.com/document/skripsihubungan-motivasi-dengan-perilaku-mengotrolkadar-gula-darah.html

Tombokan, V. (2015). Faktor-faktor yang Berhubungan dengan Kepatuhan Berobat Pasien Diabetes Melitus pada Praktek Dokter Keluarga di Kota Tomohon. JIKMU, 5(3).

World Health Organization (2016). Global Report On Diabetes. Medical, Endocrinology \& Metabolisme. Diakses dari: https://apps.who.int/iris/bitstream/handle/10665/ 204871/9789241565257 eng.pdf;jsessionid $=4 \mathrm{~F}$ 33887F5032FD13B0F0CA5BC26C266D?sequ ence $=1$

Andoko', Dimas Ning Pangesti ${ }^{2}$, Nurhayati*

'Program Studi llmu Keperawatan Universitas Malahayati. *Email: nurahmantahir785@gmail.com

${ }^{2}$ Akademi Keperawatan Baitul Hikmah Bandar Lampung. 